\title{
Research on the Influencing Factors of Russian Foreign Trade Based on R Language Regression Analysis
}

\author{
Shuna Zhou iiD ${ }^{1,2}$ and Chengwen Kang ${ }^{1}$ \\ ${ }^{1}$ Department of Economics, Harbin University of Commerce, Harbin 150028, Heilongjiang, China \\ ${ }^{2}$ Department of Math \& Computer, Manzhouli Vocational College of Russian, Manzhouli 021400, Inner Mongolia, China
}

Correspondence should be addressed to Shuna Zhou; 611981013@imu.edu.cn

Received 8 November 2021; Revised 25 November 2021; Accepted 6 December 2021; Published 27 December 2021

Academic Editor: Sang-Bing Tsai

Copyright (c) 2021 Shuna Zhou and Chengwen Kang. This is an open access article distributed under the Creative Commons Attribution License, which permits unrestricted use, distribution, and reproduction in any medium, provided the original work is properly cited.

\begin{abstract}
Based on the systematic analysis of the development of Russian foreign trade and the characteristics of the regional distribution structure of trade, this work further studies the influencing factors of Russia's foreign trade by using the R language regression analysis method and constructs three econometric models from import, export, and total import and export. The real effective exchange rate and various instruments and equipment and accessories are the main factors affecting Russia's import trade, energy, minerals, timber, and related products are the main factors affecting its export trade, and Russia's GDP and international oil prices are the major factors affecting the total import and export volume. A correct understanding of the factors affecting Russia's foreign trade will help to understand Russia's economic and trade development and its changing trend and provide a reliable reference value for the further expansion and optimization of economic and trade cooperation between other economies and Russia.
\end{abstract}

\section{Introduction}

Foreign trade is one of the important factors that restrict a country's economic development. With the deepening of economic globalization, foreign trade plays an increasingly important role in the development of various economies. Neoclassical free trade theory emphasizes that foreign trade should be based on different production factor endowments, but Russia is a country with abundant natural resources and has the advantage of natural resource endowments, which is the most stable and irreversible of all "comparative advantages" in the world. Foreign trade is an important channel for Russia to obtain capital and technology for its economic development. In the past two decades, Russia's foreign trade has made remarkable achievements and its position in Russia's economic development has been constantly improving. If we can correctly grasp the influencing factors of Russia's foreign trade, it will not only help to understand and grasp the development and changing trend of Russia's economic and trade but also provide important reference value and guiding significance for further expanding and optimizing the trade cooperation between other economies and Russia.

\section{Review of Related Literature}

Since Russia's social and economic transition, foreign trade has become one of the most dynamic and important sectors of the Russian economy and the only economic sector with stable growth under the situation of Russia's domestic economic downturn. Therefore, the development of Russia's foreign trade has been widely concerned by scholars at home and abroad. The research results on Russian foreign trade and its influencing factors can be roughly divided into the following categories from the perspective of research. First is the research based on the perspective of Russian import and export commodity structure, e.g., [1-3]. Cui analyzed the dislocation of Russia's trade structure and industrial structure and believed that Russia's trade structure was subject to the impact of international demand [4]; Bao compared the structure of import and export commodities of Russia's foreign trade in 2011 and 2015 and found that the 
structure of Russia's export commodities has not changed much, the structure of import commodities has basically not changed, and Russia's import and export commodities are closely related to its natural resource endowments [5]. Second is the research on the changes of Russia's economic and trade cooperation areas and trade partners, e.g., [6-10]. Kang analyzed the changes in trade between Russia and China before and after the economic sanctions imposed by the United States, Europe, and Japan on Russia due to the Ukraine crisis and concluded that "political heat and economic warmth" were the main characteristics of trade and economic cooperation between China and Russia at this stage. The complex and changeable external environment and the desire to participate in global governance prompted Russia to strengthen cooperation with other economies [11]. $\mathrm{Qu}$ and $\mathrm{Su}$ used the data of Russian foreign trade and attracting foreign investment to examine the evolution of Russian geo-economy. It is found that Russia's substantial dependence on Europe has not changed fundamentally, but due to the deterioration of the Ukraine crisis and the geopolitical relations between the West, the European market position has declined dramatically, and the market share of the Asia-Pacific region has increased rapidly, which has promoted Russia to speed up the pace of "turning eastward" in its geo-economy [12]. Guseltov a senior researcher at the Institute of European Studies of the Russian Academy of Sciences, also pointed out that, in order to reduce the losses suffered by the Russian economy in the global financial crisis, Russia's foreign trade carriers will gradually shift from the West to the East [13]. Third is the research on Russia's foreign trade policy and economic system, e.g., [14-18]. Kubo analyzed the institutional basis of "Russian disease" and found that the allergic reaction of Russian foreign trade to the trend of oil price has the role of institutional factors [19]. Liang analyzed the process and characteristics of the evolution of Russia's foreign trade system, pointing out that there is a big gap between Russia's foreign trade system and the requirements of WTO, and the adjustment process will take a long time [20]. As a transitional economy country, the task of Russia's foreign trade system reform is very complex. Liu summarized Russia's foreign trade strategy and corresponding policies and found the evolution of Russia's trade strategy from "import substitution" to "shock therapy" and then to "energy stick" [21]. $\mathrm{Lu}$ analyzed the reform of Soviet-Russian foreign economic and trade policy and system and believed that the reform of foreign economic and trade system was largely influenced by the reform of the whole economic system, and the two were inseparable [22].

To sum up, the existing research literature is mainly based on the perspectives of Russia's foreign trade commodity structure, trade regional structure, and trade policy, mostly qualitative analysis, lacking quantitative analysis based on quantitative models. On the basis of sorting out and analyzing the changes and development characteristics of Russia's foreign trade, this paper uses $\mathrm{R}$ language regression technology to make a quantitative analysis of the influencing factors of Russia's foreign trade, which will provide a reliable theoretical and methodological reference for a comprehensive and in-depth understanding of the characteristics of Russian foreign trade and grasping the main factors affecting Russian foreign trade.

\section{An Analysis of the Development and Characteristics of Russian Foreign Trade}

3.1. The Development of Russia's Foreign Trade and Its Impact on Domestic Economy. Russia's foreign trade has experienced a process of development from small to large and ups and downs under the external environment of world economic fluctuations and sanctions imposed by Western countries. According to the import and export data of Russia's foreign trade commodities provided by the World Trade Organization, the International Monetary Fund, and the World Bank from 1992 to 2019, we can draw a trend chart, as shown in Figure 1.

In Figure 1, we can see that Russia's imports and exports of goods have experienced three distinct troughs, with largescale declines in 1998, 2009, and 2014. The main reasons are the Asian financial crisis in 1997, the world financial crisis in 2008, and the sanctions of western countries and its impact, but the impact of each period on Russia's foreign trade is different. The impact of the Asian financial crisis in 1997 on Russia's foreign trade has the characteristics of a relatively small reduction in the scale of imports and exports and a slow recovery of the scale of imports and exports. After Putin came to power in 2000, he adjusted the strategic direction of Russia's foreign trade to "export-oriented energy products." During his nearly ten years in power, Russia's foreign trade volume has shown a steady upward trend, which, on the one hand, not only reflects that Russia's ties with the world economy are becoming closer and closer but also means that Russia will bear the adverse effects of changes in the external economic environment. The global financial crisis triggered by the subprime mortgage crisis in the United States in 2008 has brought a huge impact on Russia's foreign trade, which has sharply reduced its trade scale. In 2009, the export volume and import volume decreased by $35.7 \%$ and $34.3 \%$, respectively, compared with the same period last year. However, the impact lasted for a short time, and in 2010, Russia's import and export volume began to rise rapidly. By 2012, it reached a record high. However, the good times did not last long. The Ukraine incident in 2014 triggered economic sanctions against Russia by Europe, the United States, and Japan, which led to the continuous deterioration of the external conditions for its economic development and seriously hindered the development of its foreign trade. It was not until 2017 that Russia's trade scale began to expand gradually. From the perspective of trade balance, because Russia's export volume is always greater than its import volume, its trade balance is in a surplus state all the year round.

Foreign trade dependence, also known as foreign trade coefficient, reflects a country's dependence on the international market and is an important indicator to measure the degree of opening up of a country. The foreign trade coefficient is calculated by dividing a country's total imports and exports by its gross national product or GDP. From 1992 


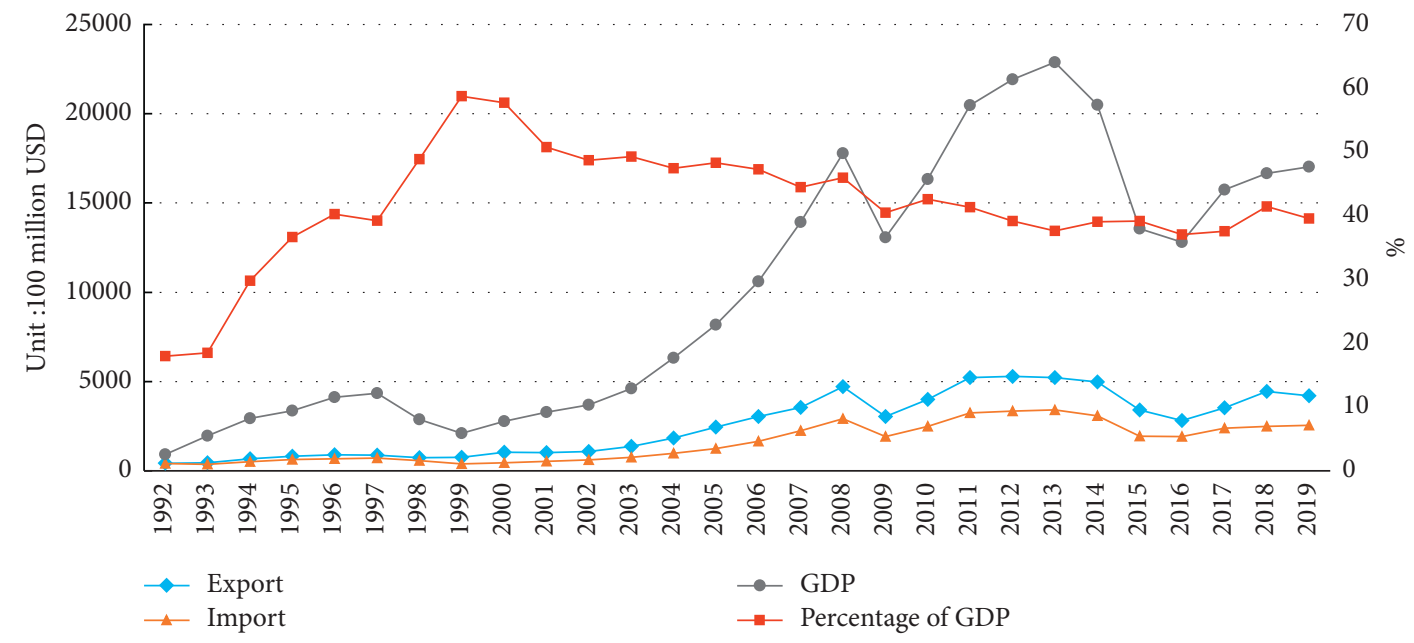

Figure 1: Trends in Russia's GDP, total imports, and exports of goods in 1992-2019.

to 2019, Russia's average annual dependence on foreign trade was $45.6 \%$, of which the dependence on export trade was $27.8 \%$ and the dependence on import trade was $17.8 \%$. Obviously, Russia maintains a high degree of trade dependence, which shows that Russia's foreign trade is highly dependent on the international market, especially Russia's export trade. Through calculation, the average annual growth rate of Russia's foreign trade from 1992 to 2019 is $10.7 \%$, which means that Russia's foreign trade plays an engine role in promoting economic development and plays a leading role in Russia's economic development.

\subsection{Characteristics of Russia's Foreign Trade Commodity} Structure. The United Nations Statistics Division database provides three system classifications of trade commodities, namely, HS, SITC, and BEC. The purpose of BEC is to aggregate basic item numbers of SITC data by major end use or economic categories of internationally traded goods. The main difference between the SITC and the HS is that SITC Code focuses more on the economic function of products at all stages of development because it was originally developed for statistical purposes. It must be used in association with a tariff classification. The HS code deals with the various categories of accurately classified products, and the coding categories are "unified" relative to the categories of the United Nations and the European Community, which is currently an internationally recognized commodity sales classification method.

Therefore, in this paper, according to the commodity trade data provided by the United Nations Commodity Exchange Database based on the "Convention on the Harmonized System of Commodity Names and Codes" (abbreviated as HS), the number of times (frequency) that Russia's trade exports and imports appeared in the top ten commodities from 1996 to 2019 is collated and counted, as shown in Table 1.

As can be seen from the statistical data in Table 1, from 1996 to 2019, Russia has 15 categories of commodities in the top ten of export commodities, of which 6 categories of commodities are in the list all the year round, namely, HS code 27 "mineral fuels, mineral oils, and their distillation products," HS code 31 "fertilizers," HS code 44 "wood and wood products," HS code 72 "iron and steel raw materials," HS code 76 "aluminium and its products," and HS code 84 "nuclear reactors, boilers, mechanical appliances, and parts." The export amount of these six categories of commodities accounts for about 4/5 of the total amount of Russia's export commodities, which is enough to show that Russia's export commodities are very single, and through observation, we can find that most of these commodities are natural resources commodities such as mineral fuels and base metals with low added value, which also reflects that Russia's foreign export trade has the advantage of natural resources endowment.

Most of Russia's imports are industrial manufactured goods with a higher degree of processing, of which three categories of goods have always been in the top ten in terms of import volume, namely, HS code 84 "nuclear reactors, boilers, mechanical appliances, and parts," HS code 85 "electrical, electrical, audio-visual equipment, and accessories," and HS code 90 "optical, photographic, medical, and other equipment and accessories." This result shows that Russia is highly dependent on the import of commodities with high added value, such as machinery, electrical equipment, and other related products. In recent years, although Russia's import commodity structure has changed, increasing the import of fruits and nuts, aerospace and aviation parts, and related manufactured goods, on the whole, Russia's import commodity structure has not changed much.

\subsection{Regional Distribution of Russia's Foreign Trade Partners.} According to the data provided by the United Nations Commodity Exchange Database from 1996 to 2019, we have counted the frequency of the top ten countries or economies in foreign trade with Russia, as shown in Table 2.

It can be clearly seen from Table 2 that Russia's main import trade countries from 1996 to 2019 are 14 countries 
TABLE 1: Russia's top ten commodities in terms of import and export volume in 1996-2019 and the frequency of their appearance.

\begin{tabular}{lcccccccccccccccccccc}
\hline \multirow{2}{*}{ Export goods } & HS code & 27 & 31 & 44 & 72 & 76 & 84 & 99 & 71 & 75 & 74 & 10 & 28 & 85 & 88 & 29 & - & - & - \\
& Frequency & 24 & 24 & 24 & 24 & 24 & 24 & 22 & 17 & 15 & 14 & 8 & 7 & 7 & 4 & 2 & - & - & - \\
\multirow{2}{*}{ Import goods } & HS code & 84 & 85 & 90 & 30 & 87 & 73 & 39 & 02 & 99 & 72 & 08 & 28 & 17 & 88 & 27 & 24 & 48 & 40 \\
& Frequency & 24 & 24 & 24 & 23 & 22 & 21 & 19 & 18 & 16 & 14 & 10 & 6 & 5 & 5 & 4 & 2 & 2 & 1 \\
\hline
\end{tabular}

TABLE 2: Top 10 countries and frequencies of Russia's trade imports and exports in 1996-2019.

\begin{tabular}{|c|c|c|c|c|c|c|c|c|c|c|}
\hline \multirow{4}{*}{ Export trade } & Country & Belarus & Germany & USA & Italy & UK & Ukraine & Finland & Poland & Ireland \\
\hline & Frequency & 24 & 24 & 14 & 23 & 12 & 17 & 3 & 18 & 1 \\
\hline & Country & Netherlands & Switzerland & China & Japan & Korea & Kazakhstan & Turkey & \multicolumn{2}{|c|}{$\begin{array}{l}\text { Other countries } \\
\text { or region }\end{array}$} \\
\hline & Frequency & 24 & 11 & 24 & 8 & 6 & 7 & 17 & \multicolumn{2}{|c|}{7} \\
\hline \multirow{4}{*}{ Import trade } & Country & Belarus & Germany & USA & Italy & UK & Ukraine & Finland & & and \\
\hline & Frequency & 24 & 24 & 24 & 24 & 10 & 23 & 10 & & \\
\hline & Country & France & Brazil & China & Japan & Korea & Kazakhstan & \multicolumn{3}{|c|}{ Other countries or region } \\
\hline & Frequency & 24 & 2 & 22 & 17 & 15 & 14 & \multicolumn{3}{|c|}{2} \\
\hline
\end{tabular}

such as Belarus, Germany, the United States, Italy, and France, and the main export trade countries are 16 countries such as Belarus, China, Germany, and the Netherlands. From Table 2, we can easily find that Russia has the closest trade cooperation with Belarus and Germany in both export and import trade.

According to the data from 1995 to 2018 provided by the Statistical Office of the Russian Federation, the distribution of Russia's foreign trade in various regions of the world and its trade scale can be further analyzed, as shown in Table 3. In terms of export trade, Russia's export scale from all regions of the world is in the following order: Europe, Asia, CIS, America, Africa, and Oceania, accounting for $53.8 \%, 4.7 \%, 15.6 \%, 4.2 \%, 1.6 \%$, and $0.1 \%$ of Russia's total exports, respectively. In terms of import trade, Russia's main import source countries or regions are Europe, Asia, CIS, America, Oceania, and Africa, accounting for $44.3 \%, 30.2 \%, 15.8 \%, 9 \%, 4 \%$, and $0.3 \%$ of Russia's total import value, respectively. It can be seen that Europe is the most important trade region in Russia's foreign trade, whether import or export. In addition, the trade volume between Russia and Africa and Oceania is relatively small, indicating that the regional distribution of trade in Russia is extremely unbalanced.

\section{Quantitative Analysis of the Factors Influencing Russia's Foreign Trade}

International trade theory tells us that the differences in factor endowments, consumption preferences, and technological level among countries are the basis of international division of labor and international trade, and these factors may also be the main reasons affecting the development of foreign trade among countries. Based on the theory of economy and trade, this paper studies the main influencing factors of Russia's foreign trade by establishing econometric models and using quantitative analysis methods, which will help to grasp the development trend of Russia's foreign trade and has important practical guiding significance for improving economic and trade cooperation with Russia.
4.1. Variable Selection and Model Construction. As a big country in the world, Russia has special national conditions and has experienced a tortuous course of economic development, which determines the complexity of the factors affecting Russia's foreign trade. Its trade level is affected not only by its own factor endowments and the level of domestic economic and social development but also by changes in the external political and economic environment. Because foreign trade is divided into export trade and import trade, it is necessary to establish the export model and the import model, respectively, to analyze the influencing factors of Russian foreign trade. It should be noted that when the total value of imports is greater than that of exports, there will be a trade surplus, and when the total value of exports is greater than that of imports, there will be a trade deficit, and both trade surplus and trade deficit will have an impact on a country's foreign trade status and the development of its national economy, which also needs to be analyzed in combination with the overall situation of exports and imports. We need to establish three models to study the factors affecting Russia's foreign trade, namely, import trade model, export trade model, and the total import and export model.

4.1.1. Selection of Dependent Variables. The dependent variables refer to the variable that can measure the research object. The research object in this paper is Russia's foreign trade, and it is investigated from the import trade and export trade, respectively. Therefore, the import amount, export amount, and total import and export amount of Russian foreign trade commodities can be selected as the explained variables of the import model, export model, and total import and export model, which are recorded as IM, EX, and JCKZE, respectively, where JCKZE $=\mathrm{EX}+\mathrm{IM}$.

4.1.2. Selection of Independent Variables. Russia's gross domestic product (GDP): Meade, a famous British economist, proved that the foreign trade situation of a country or region is mainly affected by its domestic economic changes [23]. According to macroeconomic theory, the best indicator 
TABLE 3: Regions and trade volume of Russia's import and export trade in 1995-2018. Unit: USD million.

\begin{tabular}{|c|c|c|c|c|c|c|c|c|c|c|c|c|}
\hline \multirow{2}{*}{ Year } & \multicolumn{2}{|c|}{ Europe } & \multicolumn{2}{|c|}{ Asia } & \multicolumn{2}{|c|}{ Africa } & \multicolumn{2}{|c|}{ America } & \multicolumn{2}{|c|}{ Oceania } & \multicolumn{2}{|c|}{ CIS } \\
\hline & Export & Import & Export & Import & Export & Import & Export & Import & Export & Import & Export & Import \\
\hline 1995 & 38079 & 22235 & 13646 & 4353 & 592 & 112 & 5044 & 3519 & 31 & 246 & 14556 & 13689 \\
\hline 1996 & 40697 & 19303 & 14784 & 4857 & 542 & 77 & 5879 & 3995 & 12 & 241 & 15895 & 14549 \\
\hline 1997 & 41287 & 24033 & 13835 & 5673 & 575 & 76 & 5383 & 5496 & 15 & 326 & 16624 & 14234 \\
\hline 1998 & 33984 & 18919 & 11152 & 4795 & 577 & 174 & 4937 & 5642 & 14 & 285 & 13699 & 11313 \\
\hline 1999 & 36072 & 13102 & 11893 & 3102 & 757 & 136 & 5393 & 3797 & 9 & 172 & 10707 & 8343 \\
\hline 2000 & 53028 & 13323 & 18397 & 3340 & 712 & 73 & 5363 & 3754 & 7 & 199 & 13818 & 11603 \\
\hline 2001 & 50745 & 18227 & 18806 & 5088 & 882 & 71 & 4810 & 5001 & 17 & 178 & 14706 & 11204 \\
\hline 2002 & 54284 & 21720 & 20845 & 6512 & 929 & 83 & 4559 & 5062 & 14 & 157 & 15710 & 10163 \\
\hline 2003 & 66421 & 26485 & 29599 & 9126 & 853 & 125 & 4970 & 5220 & 27 & 155 & 20494 & 13137 \\
\hline 2004 & 89901 & 34046 & 39719 & 13987 & 1379 & 156 & 7866 & 5506 & 44 & 208 & 29471 & 17712 \\
\hline 2005 & 135863 & 43812 & 46377 & 21775 & 1807 & 225 & 7824 & 8199 & 48 & 308 & 32617 & 18995 \\
\hline 2006 & 174734 & 61435 & 52952 & 34448 & 2290 & 364 & 10381 & 11507 & 33 & 583 & 42311 & 22373 \\
\hline 2007 & 194704 & 86844 & 68296 & 55967 & 4048 & 520 & 10578 & 16418 & 53 & 742 & 52661 & 29870 \\
\hline 2008 & 260396 & 115945 & 87700 & 78034 & 4150 & 884 & 18205 & 22039 & 87 & 1173 & 69656 & 36606 \\
\hline 2009 & 157794 & 75292 & 63768 & 44102 & 3945 & 579 & 11592 & 15337 & 163 & 715 & 46811 & 21818 \\
\hline 2010 & 205749 & 95311 & 88467 & 69601 & 3904 & 676 & 16082 & 18157 & 132 & 920 & 59685 & 31606 \\
\hline 2011 & 258327 & 127331 & 115842 & 92285 & 6395 & 1018 & 20760 & 22767 & 71 & 1232 & 79435 & 44841 \\
\hline 2012 & 266538 & 132327 & 120194 & 97602 & 7499 & 913 & 16609 & 23554 & 115 & 1111 & 78107 & 41642 \\
\hline 2013 & 264146 & 133393 & 124485 & 97595 & 5216 & 1044 & 15124 & 24970 & 404 & 1053 & 73490 & 41309 \\
\hline 2014 & 236105 & 116866 & 129964 & 89724 & 7098 & 1175 & 15391 & 25929 & 550 & 913 & 64186 & 33287 \\
\hline 2015 & 152629 & 69702 & 95351 & 59867 & 6500 & 909 & 13156 & 16681 & 506 & 693 & 45092 & 21210 \\
\hline 2016 & 120862 & 69265 & 79443 & 61953 & 8852 & 964 & 12874 & 15295 & 142 & 619 & 37966 & 19790 \\
\hline 2017 & 149910 & 85665 & 103469 & 79121 & 12119 & 1128 & 15309 & 18426 & 204 & 727 & 48079 & 24856 \\
\hline 2018 & 191320 & 88612 & 134848 & 86280 & 13607 & 1119 & 18455 & 17548 & 168 & 807 & 54889 & 26467 \\
\hline
\end{tabular}

to measure a country's economic changes is its GDP, which is the main factor determining the demand for its imports. Therefore, the gross domestic product of Russia is used as a representative variable of the level and scale of Russian economic development.

Real effective exchange rate (denoted by the symbol " $e$ "): foreign trade is based on the relative price difference. According to the transmission mechanism of exchange rate trade, the change of the exchange rate level will change the elasticity of supply and demand of foreign trade commodities, thus affecting the change of a country's foreign trade balance. Therefore, the exchange rate level is introduced into the model to examine whether it has a significant impact on Russia's foreign trade.

International oil price (denoted by the symbol " $P$ ”): in the process of industrialization in the world, oil is one of the important energy and strategic commodities. Russia has the advantage of natural resource endowment and has become one of the world's important exporters of oil and other natural resources. Changes in international oil prices will have an impact on Russia's oil exports. However, whether international oil prices have a causal impact on the overall development of Russia's foreign trade needs to be further tested by introducing the model.

Type of trade goods: foreign trade commodities and their structure are the direct embodiment of the connotation and structure of a country's foreign trade, which can reflect the trade interests between trading partners and the status of international division of labor. In this paper, according to the 22 categories under the HS commodity code and then according to the ranking of various trade commodities, the data statistics integration and classification processing are carried out, and finally, the commodity type variables of Russia are determined. Among them, there are six trade commodity variables in the export model, which are represented by the symbol $\mathrm{CK}_{\mathrm{i}}(i=1,2, \ldots, 6)$. The commodity types represented by each variable are as follows: CK1 represents "agricultural products," CK2 represents "energy and mineral products," CK3 represents "chemical raw materials and related products," CK4 represents "wood and wood products," CK5 represents "metal minerals and their products," and CK6 represents "mechanical and electrical products and related products." Finally, nine trade commodity variables of the import model are determined, which are represented by symbols $\mathrm{JK}_{\mathrm{j}}(j=1,2, \ldots, 9)$. The types of commodities represented by each variable are as follows: JK1 stands for "animal and plant products," JK2 stands for "energy and mineral products," JK3 stands for "chemical raw materials and related products," JK4 stands for "plastics and rubber and related products," JK5 represents "wood pulp and its products," JK7 stands for "mechanical, electrical, and accessories," JK8 stands for "vehicles and accessories," and JK9 stands for "optical, photographic, medical, and other equipment and accessories." There are 9 trade commodity variables in the total import and export model, represented by the symbol $\mathrm{JCKSP}_{k}(k=1,2, \ldots, 9)$. The commodity categories represented by each variable are JCKSP1 represents "animal, plant, and related food," JCKSP2 represents "energy and mineral products," JCKSP3 represents "chemical raw materials and related products," JCKSP4 represents "plastics, rubber, and related products," JCKSP5 represents "wood, wood pulp, and related product." JCKSP6 
stands for "metal minerals and related products," JCKSP7 stands for "mechanical, electrical, and related products," JCKSP8 stands for "transportation equipment and accessories," and JCKSP9 represents "various instruments and accessories."

4.1.3. Data Sources and Model Building. After the disintegration of the Soviet Union, the Russian economy experienced about three years of violent turbulence and began to adjust in 1993. In 1996, its domestic economic policy entered a relatively stable period. Except for the impact of the 1998 financial crisis, there was no major turning point for policy adjustment, privatization had been completed, and the resource-dependent economic growth model was still continuing. Based on this, 1996 is selected as the data source point. Due to the limitation of data statistical standards and acquisition of each platform and in order to ensure the validity and consistency of the data as far as possible, the time span of all sample data in the model is unified as 1996-2019. Among them, the data of GDP (unit: 1 billion \$) and real effective exchange rate (based on consumer price index, with 2010 as the base year) are from the world bank database (https://data.worldbank.org.cn/). The data of international oil price (unit: USD/barrel) are from the world energy database (https://www.bp.com/). The data of export trade volume (unit: 100 million \$), import trade volume (unit: 100 million \$), and export amount and import amount of various commodities (unit: USD) are derived from the
United Nations commodity trade database (https:// comtrade.un.org/). In order to reduce the scale of variables and eliminate the possible heteroscedasticity in the data, each variable is transformed into a natural logarithm. According to the economic theory and practical experience of foreign trade, the model is constructed as a linear regression model. The corresponding export trade model, import trade model, and total import and export model are as follows:

$$
\begin{aligned}
\ln \mathrm{EX}= & \alpha_{0}+\alpha_{1} \ln \mathrm{GDP}+\alpha_{2} \ln e+\alpha_{3} \ln P \\
& +\alpha_{4} \ln \mathrm{CK}_{1}+\alpha_{5} \ln \mathrm{CK}_{2}+\alpha_{6} \ln \mathrm{CK}_{3} \\
& +\alpha_{7} \ln \mathrm{CK}_{4}+\alpha_{8} \ln \mathrm{CK}_{5}+\alpha_{9} \ln \mathrm{CK}_{6}+\mu .
\end{aligned}
$$

$\alpha_{0}, \alpha_{i}(i=1,2, \ldots, 6)$, and $\mu$ are the intercept term, regression parameter, and error term of the export trade model, respectively:

$$
\begin{aligned}
\ln \mathrm{IM}= & \beta_{0}+\beta_{1} \ln \mathrm{GDP}+\beta_{2} \ln e+\beta_{3} \ln P \\
& +\beta_{4} \ln \mathrm{JK}_{1}+\beta_{5} \ln \mathrm{JK}_{2}+\beta_{6} \ln \mathrm{JK}_{3} \\
& +\beta_{7} \ln \mathrm{JK}_{4}+\beta_{8} \ln \mathrm{JK}_{5}+\beta_{9} \ln \mathrm{JK}_{6} \\
& +\beta_{10} \ln \mathrm{JK}_{7}+\beta \ln \mathrm{JK}_{8}+\beta_{12} \ln \mathrm{JK}_{9}+\varepsilon .
\end{aligned}
$$

$\beta_{0}, \beta_{j}(j=1,2, \ldots, 9)$, and $\varepsilon$ are the intercept term, regression parameter, and error term of the import trade model, respectively:

$$
\begin{aligned}
\ln \mathrm{JCKE}= & \gamma_{0}+\gamma_{1} \ln \mathrm{GDP}+\gamma_{2} \ln e+\gamma_{3} \ln P+\gamma_{4} \ln \mathrm{JCKSP}_{1}+\gamma_{5} \ln \mathrm{JCKSP}_{2} \\
& +\gamma_{6} \ln \mathrm{JCKSP}_{3}+\gamma_{7} \ln \mathrm{JCKSP}_{4}+\gamma_{8} \ln \mathrm{JCKSP}_{5}+\gamma_{9} \ln \mathrm{JCKSP}_{6} \\
& +\gamma_{10} \ln \mathrm{JCKSP}_{7}+\gamma_{11} \ln \mathrm{JCKSP}_{8}+\gamma_{12} \ln \mathrm{JCKSP}_{9}+\tau
\end{aligned}
$$

$\gamma_{0}, \gamma_{k}(k=1,2, \ldots, 9)$, and $\tau$ are the intercept term, regression parameter, and error term of the total import and export model, respectively.

\section{2. $R$ Language Regression and Result Analysis}

4.2.1. OLS Regression Analysis of the Export Model. The export trade model is estimated by least squares regression using $\mathrm{R}$ software, and the following regression results are obtained:

$$
\begin{aligned}
\widehat{\ln \mathrm{EX}}= & -14.619+0.180 \ln \mathrm{GDP}+0.110 \ln P-0.029 \ln e+0.006 \ln \mathrm{CK}_{1}+0.214 \ln \mathrm{CK}_{2} \\
& +0.235 \ln \mathrm{CK}_{3}(-7.592)(1.473)(1.088)(-0.169)(0.229)(1.966)(2.966)+0.264 \ln \mathrm{CK}_{4} \\
& +0.001 \ln \mathrm{CK}_{5}+0.021 \ln \mathrm{CK}_{6}(2.269)(0.012)(0.283)
\end{aligned}
$$

Multiple $R$ - squared: 0.9989, Adjusted $R$ - squared: 0.9982,

$F$ - statistic: 1446 on 9 and $14 \mathrm{DF}, p$ value: $<2.2 e-16$.

According to the regression results, when the significance level is $\alpha=0.05$, only two explanatory variables, In CK3 and ln CK4, pass the $t$-test in this model, but the goodness of fit $\bar{R}^{2}$ of this model is as high as 0.9982 , indicating that the model may have serious multicollinearity. A variance inflation factor (VIF) test is performed for each explanatory variable, $\operatorname{VIF}_{i}=1 /\left(1-\bar{R}^{2}\right)$, where $\bar{R}^{2}$ is the goodness of fit of each explanatory variable to all other explanatory variables. It can be seen that the greater the goodness of fit, the greater the correlation between 
explanatory variables. Experience shows that when VIF $\geq 10$, there is serious multicollinearity between explanatory variables and other explanatory variables, and this multicollinearity may excessively affect the least squares estimation. Through calculation, we find that the Vif value of each explanatory variable is greater than 10 . Therefore, it can be confirmed that there is serious multicollinearity among the variables in the model. The Frisch stepwise regression method is used to solve the problem of multicollinearity. First, the explained variables are regressed separately for each explanatory variable, and the coefficients of determination in the regression results are sorted from large to small. In Table 4 , the goodness of fit, $t$-value, and the corresponding cumulative probability value of $t$-statistic of the univariate regression of the dependent variable ln EX to each explanatory variable are shown (when the significance level is $\alpha=0.05$ ).

According to Table 4, $\operatorname{lnCK} 2$ can be determined as the explanatory variable of the basic regression equation, and then, the principle of backward stepwise regression is used to delete unnecessary explanatory variables, and finally, the explanatory variables of the export model are $\ln \mathrm{GDP}, \ln C \mathrm{~K} 2$, $\operatorname{lnCK} 3$, and CK4. The above explanatory variables were used to perform $\mathrm{R}$ software regression again, and the results are shown in Table 5.

At this time, all the explanatory variables passed the $t$ test (at the significance level of 0.05), and the value of goodness of fit was also ideal. In order to ensure the validity of the regression results, it is necessary to test the distribution characteristics of the model residuals. Through $\mathrm{R}$ software, we can get four residual series analysis charts in
Figure 2: (1)-(4) are residual chart, normal distribution distance chart, residual distance trend distribution chart, and Cook distance chart, respectively. It can be preliminarily judged from the graph that the residual series of the model has no heteroscedasticity and is a stationary series tending to normal distribution.

In order to avoid the phenomenon of "false regression," it is necessary to test the stationarity of the model. In this paper, Phillips-Perron unit root stationarity test method is used. The test results are shown in Table 6. The results show that all explanatory variables are nonstationary sequences. However, because the residual series of the model is stationary, it shows that there may be a cointegration relationship in the model; that is, there is a long-term equilibrium relationship between the variables.

To further test the single integral order of the nonstationary series, the final form of the Phillips-Perron unit root stationarity test for each variable is PP.test(diff $(\operatorname{lnEX})$ ), PP.test(diff (lnGDP, 1, 2)), PP.test(dif (lnCK2)), PP.test (diff $(\operatorname{lnCK} 3))$, and PP.test(diff $(\operatorname{lnCK} 4,1,2))$. It shows that the single integer order of time-series variables $\operatorname{lnEX}, \operatorname{lnCK} 2$, and $\operatorname{lnCK} 3$ is 1 , while the single integer divisor of time-series variables $\ln \mathrm{GDP}$ and $\ln \mathrm{CK} 4$ is 2 . According to the determination principle of cointegration relationship, in the system composed of multiple variables, the residual series is stable, and the single integer divisor of other variables is the same; there may be partial or complete cointegration relationship. Therefore, there is a cointegration relationship in this model. Finally, R software regression analysis is carried out to obtain the regression results of the cointegration model as follows:

$$
\begin{aligned}
\widehat{\ln \mathrm{EX}}= & -16.23237+0.154032 \ln \mathrm{GDP}+0.311254 \ln \mathrm{CK}_{2}+0.255848 \ln \mathrm{CK}_{3} \\
& +0.278250 \ln \mathrm{CK}_{4}(-56.33534)(4.097999)(8.643809)(5.742302)(8.646997), \\
& \text { Multiple } R-\text { squared: } 0.998804, \text { Adjusted } R \text { - squared: } 0.998552, \text { S.E. of regression: } 0.027352, \\
& F-\text { statistic: } 3966.597, \text { Durbin }- \text { Watson stat: } 1.711806 .
\end{aligned}
$$

The empirical results show that, in the long run, when Russia's GDP changes by $1 \%$, Russia's commodity export trade will change by $0.154 \%$. When the export volume of CK2 (energy and mineral products), CK3 (chemical raw materials and related products), and CK4 (timber and its products) changes by $1 \%$, Russia's commodity export trade will change by $0.311 \%, 0.256 \%$, and $0.278 \%$, respectively. Therefore, among the many factors affecting the export to Russia, Russia's economic development level, energy, minerals, timber, and other natural resources, as well as chemical raw materials and related products, have a longterm impact on Russia's export. According to the $t$-value of significance test in the regression results, it can also be seen that energy minerals and timber and related products are the most important factors affecting the export trade of Russia.

4.2.2. OLS Regression Analysis of the Import Model. Next, the OLS regression analysis is performed on the import model, and the specific process is the same as above. The results showed that except for the explanatory variables $\ln \mathrm{GDP}, \ln \mathrm{JK} 3$, and $\ln J \mathrm{~K} 6$, which passed the significance test, the other explanatory variables did not pass the $t$-test. However, the goodness of fit $\bar{R}^{2}$ of the model is as high as 0.9985 , which indicates that the model has serious multicollinearity. The Frisch stepwise regression method was used to regress, and the final regression results are as follows: 
TABLE 4: The univariate regression result of $\ln$ EX to each explanatory variable.

\begin{tabular}{lccccccccc}
\hline Variables & Ln $\mathrm{CK}_{2}$ & Ln CK & Ln GDP & Ln $p$ & Ln CK & Ln $C_{5}$ & Ln $C_{6}$ & Ln CK & Ln $e$ \\
\hline$t$-value & 37.97 & 27.28 & 25.91 & 19.01 & 16.78 & 15.45 & 11.827 & 11.77 \\
$\operatorname{Pr}(>|t|)$ & $<2 E-16$ & $<2 E-16$ & $<2 E-16$ & $3.84 E-15$ & $5.02 E-14$ & $2.72 E-13$ & $5.25 E-11$ & $5.76 E-11$ & $9.36 E-08$ \\
Goodness of fit & 0.985 & 0.9713 & 0.9683 & 0.9426 & 0.9276 & 0.9156 & 0.8641 & 0.863 & 0.7334 \\
\hline
\end{tabular}

TABLE 5: R language regression results for the export model Lm (formula $=\mathrm{LNnx} \sim \mathrm{LNgdp}+\mathrm{LNck} 2+\mathrm{LNck} 3+\mathrm{LNck} 4$ ).

\begin{tabular}{|c|c|c|c|c|c|}
\hline Residuals & $\begin{array}{c}\text { Min } \\
-0.055641\end{array}$ & $\begin{array}{c}1 \mathrm{Q} \\
-0.005193\end{array}$ & $\begin{array}{c}\text { Median } \\
-0.000711\end{array}$ & $\begin{array}{c}3 \mathrm{Q} \\
0.01698\end{array}$ & $\begin{array}{c}\text { Max } \\
0.049812\end{array}$ \\
\hline Coefficients & Estimate & Std. error & $t$-value & $\operatorname{Pr}(>|t|)$ & \\
\hline Intercept & -16.23236 & 0.28814 & -56.334 & $<2 e-16$ & $* * *$ \\
\hline LNgdp & 0.15403 & 0.03759 & 4.098 & 0.000613 & $* * *$ \\
\hline LNck2 & 0.31125 & 0.03601 & 8.644 & $5.21 E-08$ & $* * *$ \\
\hline LNck3 & 0.25585 & 0.04456 & 5.742 & $1.56 E-05$ & $* * *$ \\
\hline LNck4 & 0.27825 & 0.03218 & 8.647 & $5.18 E-08$ & $* * *$ \\
\hline
\end{tabular}

Signif. codes: 0 “***” 0.001 “**” 0.01 “*” 0.05 “.” 0.1 “” 1; residual standard error, 0.02735 on 19 degrees of freedom; multiple $R$-squared, 0.9988 ; adjusted $R$ squared, 0.9986; F-statistic, 3966 on 4 and $19 \mathrm{DF} ; p$ value, $<2.2 e-16$

$$
\begin{aligned}
\widehat{\ln I M}= & -18.09087+0.53444 \ln \mathrm{GDP}+0.42070 \ln \mathrm{JK}_{9}+0.28878 \ln e(-30.238)(6.366)(5.497)(2.224) \\
& \text { Multiple } R \text { - squared: } 0.9962 \text {, Adjusted } R \text { - squared: } 0.9956, F-\text { statistic: } 1744
\end{aligned}
$$

In order to ensure the reliability of the above regression results, Phillips-Perron test is performed on the residual term, and the Dickey-Fuller value of -3.6754 and $p$ value of 0.04461 are obtained, indicating that the residual series is a stationary series. Next, White test and LM autocorrelation test were performed on the model, and Obs $* R$-squared values of the two tests were 12.646 and 1.420 , respectively. Compared with the critical value, the results showed that the model did not have heteroscedasticity and autocorrelation problems. At this time, the model has passed all the tests, and the goodness of fit is also very high, with good explanatory power.

The empirical results show that the gross national product of Russia is the most important factor affecting the import amount, and when it increases by $1 \%$, the import amount of Russia will increase by $0.53 \%$. Among the numerous imported goods, JK9 (optical, photographic, medical equipment, and accessories) has the most significant impact on the import volume. The quantitative relationship between them is that every $1 \%$ increase in JK9 will increase the import volume of Russia by $0.42 \%$. In addition, the change of the real exchange rate also has a major impact on Russia's imports, and every $1 \%$ increase in the real exchange rate will increase Russia's imports by $0.29 \%$.
4.2.3. OLS Regression Analysis of the Total Import and Export Model. The OLS regression analysis of the total import and export model is carried out, and it is also found that there is serious multicollinearity. The stepwise regression method is used to deal with the multicollinearity problem, and the estimation results of the $\mathrm{R}$ language regression equation are as shown in Table 7.

According to the regression results, it can be seen that the fitting effect of the model is very good. In order to avoid "false regression," the unit root PP stationarity test is carried out for the import and export model variables, as shown in Table 8.

The results show that the residual series of the model is stationary, which further verifies the single integral order of the unbalanced variable, and the relationship between the variable $\ln$ GDP and Ln JCKSP5 is a 2-order single integration series, and other variables are 1-order single integration series, so there is a cointegration relationship in the model, and the cointegration regression results are as follows:

$$
\begin{aligned}
\ln \widehat{\mathrm{JCK} Z E}= & -14.19024+0.29011 \ln \mathrm{GDP}+0.14697 \ln P+0.19094 \ln \mathrm{JCKSP}_{3}+0.10593 \ln \mathrm{JCKSP}_{5} \\
& +0.16495 \ln \mathrm{JCKSP}_{6}+0.14820 \ln \mathrm{JCKSP}_{7}(-23.762)(8.771)(6.909)(5.934)(3.131)(5.670)(4.218) \\
& \text { Multiple } R \text { - squared: } 0.9997, \text { Adjusted } R-\text { squared: } 0.9996, F-\text { statistic: } 1.094 e+04 .
\end{aligned}
$$




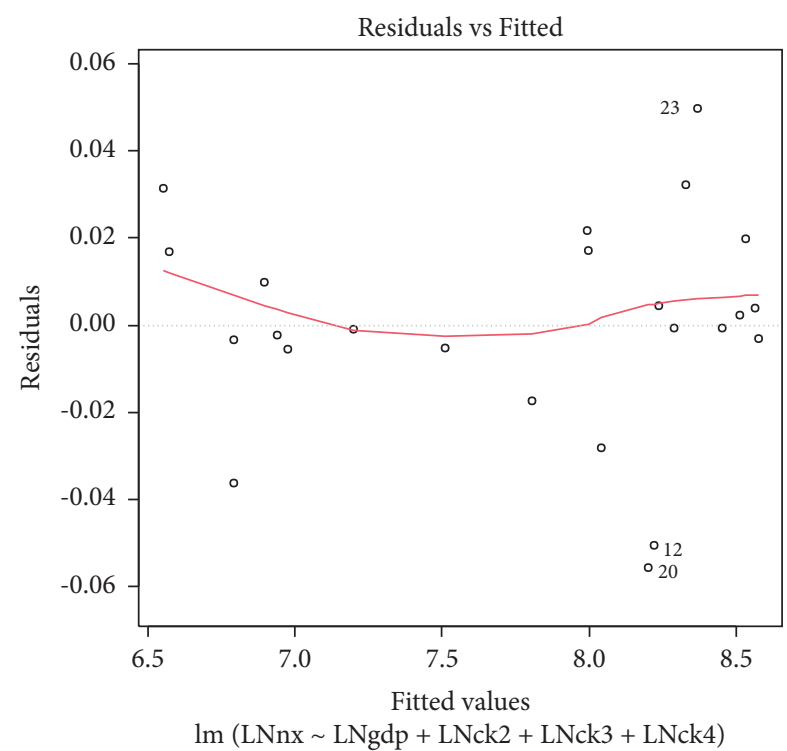

(a)

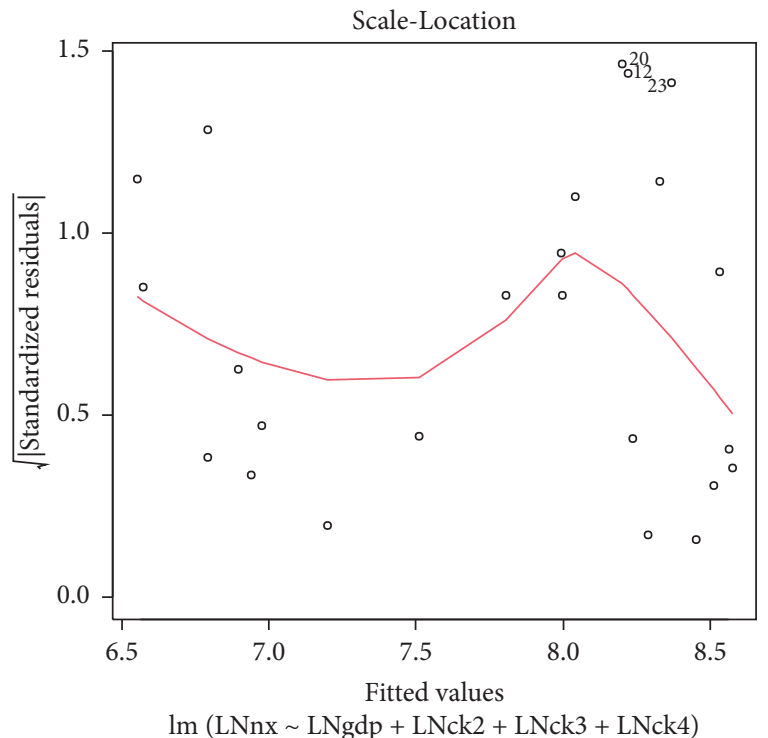

(c)

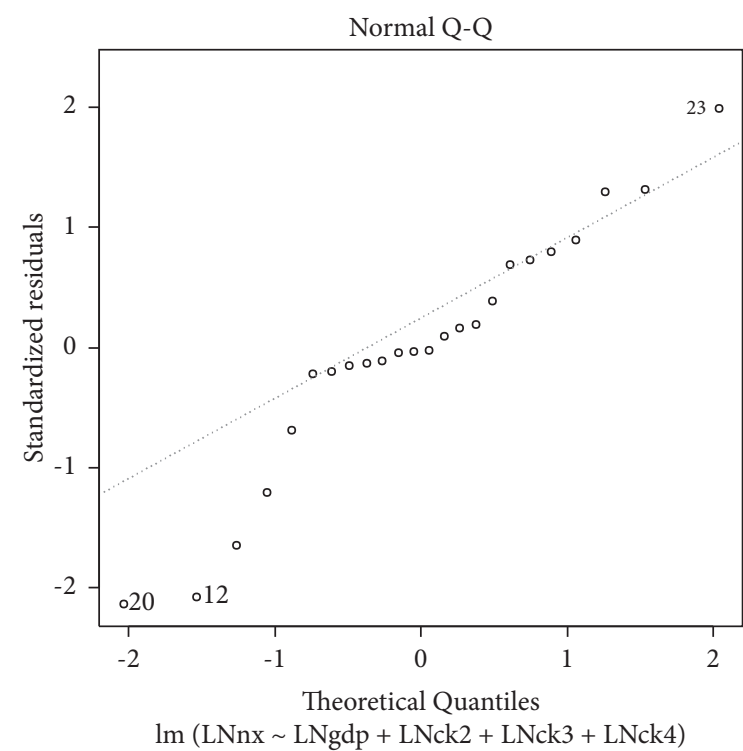

(b)

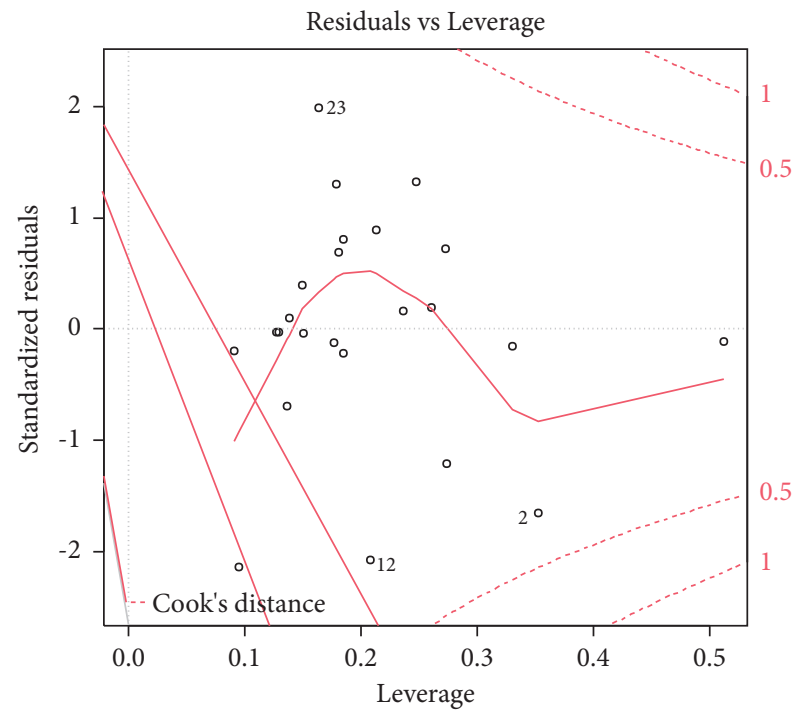

$\operatorname{lm}($ LNnx $\sim$ LNgdp + LNck2 + LNck3 + LNck4)

(d)

FIGURE 2: Residual series analysis graph.

TABLE 6: Unit root test results of the variables in the export model.

\begin{tabular}{lcccccc}
\hline Variables & Residual & Ln $E X$ & LnGDP & LnCK $_{2}$ & LnCK $_{3}$ & LnCK $_{4}$ \\
\hline Dickey-Fuller & -3.8252 & -1.2582 & -1.59 & -1.0486 & -1.732 & -1.3833 \\
$p$ value & 0.03391 & 0.855 & 0.7286 & 0.9134 & 0.6745 & 0.8073 \\
Results & Stationary & Nonstationary & Nonstationary & Nonstationary & Nonstationary & Nonstationary \\
\hline
\end{tabular}

The empirical results show that there is a long-term equilibrium relationship between the variables due to the cointegration relationship in the model. The results show that the scale of Russia's GDP has the greatest impact on its total imports and exports, followed by international oil prices. The trade commodities that have a greater impact on Russia's import and export trade are chemical raw materials and related products, wood and related products, metal minerals and related products, and mechanical and electrical commodities. The quantitative relationship between the variables is that when Russia's GDP and international oil prices increase by $1 \%$, Russia's total imports and exports will change by $0.29 \%$ and $0.147 \%$, respectively. Every $1 \%$ change in trade commodities JCKSP3 (chemical raw materials and related products), JCKSP5 (wood, wood pulp, and related products), JCKSP6 (metal minerals and related products), 
TABLE 7: $\mathrm{R}$ language regression result of the import and export total quantity model, $\mathrm{lm}$ (formula $=$ LNjckze $\sim$ LNgdp + LNp + LNjcksp3 + LNjcksp5 + LNjcksp6 + LNjcksp7).

\begin{tabular}{|c|c|c|c|c|c|}
\hline Residuals & $\begin{array}{c}\text { Min } \\
-0.0160964\end{array}$ & $\begin{array}{c}1 \mathrm{Q} \\
-0.009966\end{array}$ & $\begin{array}{c}\text { Median } \\
-0.0003718\end{array}$ & $\begin{array}{c}3 \mathrm{Q} \\
0.0044172\end{array}$ & $\begin{array}{c}\text { Max } \\
0.0236821\end{array}$ \\
\hline Coefficients & Estimate & Std. error & $t$-value & $\operatorname{Pr}(>|t|)$ & \\
\hline Intercept & -14.19024 & 0.59719 & -23.762 & $1.76 E-14$ & $* * *$ \\
\hline LNgdp & 0.29011 & 0.03308 & 8.771 & $1.02 E-07$ & $* * *$ \\
\hline $\mathrm{LNp}$ & 0.14697 & 0.02127 & 6.909 & $2.53 E-06$ & $* * *$ \\
\hline LNjcksp3 & 0.19094 & 0.03218 & 5.934 & $1.63 E-05$ & $* * *$ \\
\hline LNjcksp5 & 0.10593 & 0.03383 & 3.131 & 0.006090 & $* *$ \\
\hline LNjcksp6 & 0.16495 & 0.02909 & 5.670 & $2.77 E-05$ & $* * *$ \\
\hline LNjcksp7 & 0.14820 & 0.03513 & 4.218 & $5.78 E-04$ & $* * *$ \\
\hline
\end{tabular}

Signif. codes: 0 “***” 0.001 “**” 0.01 “*” 0.05 “.” 0.1 “” 1; residual standard error, 0.01389 on 17 degrees of freedom; multiple $R$-squared, 0.9997 ; adjusted $R$ squared, 0.9996; F-statistic, $1.094 e+04$ on 6 and $17 \mathrm{DF} ; p$ value, $<2.2 e-16$.

TABLE 8: Unit root test results of the variables in the import/export model.

\begin{tabular}{lccccccc}
\hline Variables & Residual & Ln GDP & Ln $p$ & Ln JCKSP & Ln JCKSP & Ln JCKSP $_{6}$ & Ln JCKSP $_{7}$ \\
\hline Dickey-Fuller & -5.3313 & -1.59 & -1.3888 & -1.604 & -1.0777 & -1.5839 & -1.3785 \\
$p$ value & 0.01 & 0.7286 & 0.8052 & 0.7232 & 0.9092 & 0.7309 & 0.8091 \\
Results & Stationary & Nonstationary & Nonstationary & Nonstationary & Nonstationary & Nonstationary & Nonstationary \\
\hline
\end{tabular}

and JCKSP 7 (mechanical and electrical products) will affect Russia's total import and export trade by $0.191 \%, 0.106 \%$, $0.165 \%$, and $0.148 \%$ respectively. Therefore, in the long run, GDP, international oil prices, and related trade products such as timber, metals, chemical raw materials, machinery, and electricity are the main factors affecting Russia's foreign trade.

\section{Conclusion}

Foreign trade plays an important role in Russia's economic development and occupies a leading position. However, Russia's foreign trade is highly dependent on the international market and vulnerable to changes in the international political and economic environment, and has certain security risks. At the same time, Russia's main export and import trade region is Europe, the vast majority of trading partners from the European Union, of which Russia's exports to the Netherlands, Germany, and Italy accounted for more than half of Russia's total exports to Europe. Russia's export trade is excessively dependent on a few EU countries and regions, which will further increase the risks and uncertainties of Russia's foreign trade. Through the regression analysis of R language software, we know that Russia's GDP, international oil price, and related trade products such as timber, metal, chemical raw materials, machinery, and electricity are the main factors affecting the total scale of Russia's foreign trade (including imports and exports), while energy, minerals, and timber and related products are the important factors affecting Russia's export trade.

In the context of economic globalization, in order to obtain greater trade benefits and ensure the stable development of its economy, Russia should better play its resource endowment and trade advantages, actively expand overseas markets, increase corresponding policy support, and improve the manufacturing level and processing level of related industrial products, so as to improve its international division of labor status and enhance its international competitiveness. To achieve the above means, Russia will need more economical and technological support and trade and investment cooperation from abroad in the future.

\section{Data Availability}

The data used to support the findings of this study are available from the corresponding author upon reasonable request.

\section{Conflicts of Interest}

The authors declare that they have no potential conflicts of interest with respect to the research, authorship, and/or publication of this article.

\section{Acknowledgments}

The authors would like to thank the Philosophy and Social Science Foundation Projects of China (Grant no. 16BJL039) for funding this research.

\section{References}

[1] А. А. Гнидченко, "Foreign trade in goods and services: comparing the data sources," Statistics of Russia, vol. 4, no. 27, pp. 80-87, 2020.

[2] И. В. ИГнатова and Л. А. Дударева, "Green export of Russia's to the European union: problems, opportunities and prospects," Academic Journal, vol. 6, pp. 61-69, 2021.

[3] Е. А. СтеШанов, Т. Ф. Тран, ч. Т. НГуен, И. Ш. Килина, Е. В. Николаева, and К. Ю. Несытыч, "Structural features of Russian and Vietnam foreign trade," Vestnik Chelyabinskogo Gosudarstvennogo Universiteta, vol. 11, no. 445, pp. 68-78, 2020. 
[4] K. Cui, "Literature review on the interactive relation between trade structure and industrial structure in Russia," Journal of Harbin Institute of Technology, vol. 18, no. 6, pp. 132-136, 2016.

[5] Z. Y. Bao, "An analysis of Russia's macroeconomic and foreign trade development," Foreign Economic Relations \& Trade, vol. 2, pp. 28-30, 2017.

[6] Е. А. СтеШанов, Д. А. Шлетнев, and В. Фам, “Trends and prospects of Russia-Vietnam economic cooperation: foreign trade as a mirror of economic relations," Vestnik Chelyabinskogo Gosudarstvennogo Universiteta, vol. 9, no. 431, pp. 84-91, 2019.

[7] А. Б. АлександроВич, А. О. Борисович, and Т. Н. КуанГ, "Foreign trade of Russia and Vietnam: modern trends and prospects of development," State University of Management, vol. 4, no. 8, pp. 31-41, 2020.

[8] M. Tkachenko, "Assessment of risks and benefits in trade cooperation of Russia and the countries of North Africa," Russian Journal of Management, vol. 8, no. 4, pp. 176-180, 2021.

[9] Б. Д. Лдуардович, "Analysis of the impact of tariff preferences on the foreign trade of the Russian Federation and the Republic of Serbia," State University of Management, vol. 4, no. 8, pp. $42-50,2020$.

[10] Я. А. Сучодолов, “Trade of Russia and Mongolia: trends and prospects," International Trade \& Trade Policy, vol. 1, no. 6, pp. 83-96, 2020.

[11] C. W. Kang, "The changes of Russian foreign trade under the sanctions of the United States, europe and Japan and the analysis of sino-Russian trade," Inter, vol. 5, pp. 28-36, 2016.

[12] W. Y. Qu and Z. R. Su, "The Ukraine crisis and the evolution of Russia's geo-economy," International Economic Review, vol. 2, pp. 123-141, 2019.

[13] B. P. Guseltov, "On prospects of Russian-Chinese economic cooperaiton," China Investment, vol. Z1, pp. 22-24, 2019.

[14] E. Rasoulinezhad, "A new evidence from the effects of Russia's WTO accession on its foreign trade," Eurasian Economic Review, vol. 8, no. 1, pp. 73-92, 2018.

[15] S. Kazantsev, "Russia's foreign trade under the anti-Russian sanctions," Review of Business \& Economics Studies, vol. 3, no. 6, pp. 44-56, 2018.

[16] Д. И. Ушкалова, “The evolution of Russia's specialisation in mutual trade with the countries of the EAEU," World of New Economy, vol. 4, pp. 57-66, 2018.

[17] V. M. Poletaeva and A. M. Smulov, "Certain mechanisms of establishing economy of sustainable industrial growth in Russia and problems of their implementation," Vestnik of the Plekhanov Russian University of Economics, vol. 2, no. 2, pp. 44-56, 2019.

[18] Л. В. Шкваря, "Russia and the EU foreign trade in the XXI century: traditions and modernity," International Trade \& Trade Policy, vol. 3, no. 7, pp. 106-115, 2021.

[19] M. Kubo, "The turning point of Russian economy and Russian disease," Russian Studies, vol. 1, pp. 40-91, 2012.

[20] R. Liang, "The evolution of Russia's foreign trade system under the background of China's entry into WTO," Journal of Eurasian Economy, vol. 5, pp. 14-26, 2013.

[21] J. M. Liu, "Evolutionary logic and policy choices of Russia's foreign trade strategy," Comparative Economic \& Social Systems, vol. 2, pp. 138-144, 2014.

[22] N. Q. Lu, "A review of the changes of foreign trade policies and systems in USSR-Russia," Journal of China Executive Leadership Academy Pudong, vol. 14, no. 6, pp. 125-136, 2020.

[23] J. E. Meade, Trade and Welfare: The Theory of International Economic Policy, Oxford University Press, London, UK, 1955. 